\title{
EXTREME STORM SURGES IN THE SOUTH OF BRAZIL: ATMOSPHERIC CONDITIONS AND SHORE EROSION
}

\author{
Cláudia Klose Parise ${ }^{1}$, Lauro Júlio Calliari ${ }^{2}$ and Nisia Krusche ${ }^{3}$ \\ ${ }^{1}$ Universidade Federal do Rio Grande do Sul - Geociências - Geologia Marinha \\ (Av. Bento Gonçalves, 9500 - Campus do Vale, 91509-900 Porto Alegre, RS, Brasil) \\ ${ }^{2}$ Universidade Federal do Rio Grande do Sul - Laboratório de Oceanografia Geológica \\ (Av. Itália, km 8, Campus Carreiros 96201-900 Rio Grande, RS, Brasil) \\ ${ }^{3}$ Universidade Federal do Rio Grande do Sul - Centro de Ciências Computacionais \\ (Av. Itália, km 8, Campus Carreiros, 96201-900 Rio Grande, RS, Brasil)
}

\begin{abstract}
A B S T R A C T
The region under study is regularly subject to the occurrence of storms associated with frontal systems and extratropical cyclones, since it is located near one of the cyclogenetic regions in South America. These storms can generate storm surges that cause anomalous high sea level rises on Cassino Beach. The use of reanalysis data along with an efficient technique for the location of the cyclone, using a vorticity threshold, has provided a new classification based upon the trajectories of events that produce positive sea level variation. Three patterns have been identified: 1) Cyclogenesis to the south of Argentina with displacement to the east and a trajectory between $47.5^{\circ} \mathrm{S}$ and $57.5^{\circ} \mathrm{S} ; 2$ ) Cyclogenesis to the south of Uruguay with displacement to the east and a trajectory between $35^{\circ} \mathrm{S}$ and $42.5^{\circ} \mathrm{S}$; and 3 ) Cyclogenesis to the south of Uruguay with displacement to the southeast and a trajectory between $35^{\circ} \mathrm{S}$ and $57.5^{\circ} \mathrm{S}$. Maximum water level elevation above the mean sea level and beach erosion were associated, respectively, with winter and summer storms. Cassino beach displayed a seasonal morphological behavior, with short periods of episodic erosion associated with winter storm events followed by long periods of accretion characterized by the dominance of fair weather conditions.

\section{R ESUMO}

Marés meteorológicas que geram sobre-elevações do nível do mar são freqüentes na costa do Rio Grande do Sul e respondem às variações ocorridas na atmosfera. Torna-se importante, dessa maneira, definir padrões meteorológicos sinóticos responsáveis por gerar eventos de marés meteorológicas intensas na Praia do Cassino como objetivo desse trabalho. O uso de dados de reanálise associados a uma técnica eficiente de localização do ciclone, aplicando o conceito de vorticidade, permitiu definir uma nova classificação com base na trajetória de ciclones extratropicais responsáveis pela subida do nível do mar. Três padrões de trajetórias foram identificados: 1) Ciclogênese ao sul da Argentina com deslocamento para leste e trajetória entre $47.5^{\circ} \mathrm{S}$ e $57.5^{\circ} \mathrm{S} ; 2$ ) Ciclogênese ao sul do Uruguai com deslocamento para leste e trajetória entre $35^{\circ} \mathrm{S}$ e $42.5^{\circ} \mathrm{S}$; 3) Ciclogênese ao sul do Uruguai com deslocamento para sudeste e trajetória entre $35^{\circ} \mathrm{S}$ e $57.5^{\circ} \mathrm{S}$. O estudo de 23 ciclones extratropicais permitiu verificar máximas elevações do nível e erosão respectivamente associados a tempestades ocorridas no inverno e verão. A Praia do Cassino apresentou um comportamento sazonal, com erosão episódica associada a eventos de alta energia mais freqüentes no inverno, e longos períodos de acresção relacionados ao regime hidrodinâmico normal.
\end{abstract}

Descriptors: Storm surge, Extratropical cyclone, Erosion. Descritores: Maré meteorológica, Ciclone extratropical, Erosão.

\section{INTRODUCTION}

Shore erosion and floods caused by seawaters on low-slope coasts are mainly generated by storms which cause higher rises in sea level than those of the regular tide. This rise in sea level is called a storm surge in the literature worldwide. The meteorological tide, which is basically defined as the difference in level between the predicted (astronomical) tide and the observed one, constitutes the greatest natural risk to coastal communities; thus, it is the major reason for the loss of property, natural habitats, and, ultimately, life (MURTY, 1984).

On the coast of Rio Grande do Sul state, rises of one and a half meters above the forecast tide have already been observed (ALMEIDA et al., 1997; CALLIARI et al., 1998). They lead to severe shore erosion in both urban and unoccupied areas. Erosion is maximized when the high sea level rise coincides with 
the peak of the high spring tide, when the elevation is higher.

The wind friction over the sea surface results in the transference of momentum from the atmosphere to the ocean. Therefore, strong winds that act on fetch, parallel to the continent, pile up water on the coastal zone (wind set up), whereas the low pressure associated with the cyclonic rotation increases the ocean level (the inverse barometer effect) (PUGH, 1987). The increase of the wave height in the surf also results in the rise of the water level in the surf zone, thus leading to the flooding of areas further inland than happens with the normal waves (wave set up) (BENAVENTE et al., 2006).

This rise in level usually provokes erosion, since it dislocates the coast line towards the continent, carrying the sediments out to the surf zone where they are deposited in the form of bars. In these events, the sedimentary stock is concentrated in the subaquatic region, rather than on the shore. The amplitude of the meteorological tide is also influenced locally by the intensity and duration of the wind. These result from the position and extension of the wind fetch, which is due to the position and displacement velocity of the extratropical cyclone in relation to the extratropical anticyclone on the continent.

Both the flooding caused by the high sea level rise and the morphodynamic response of the shore vary according to the distinct morphological characteristics of the shore, even in situations of equal meteorological tide amplitudes. Beaches with gentle slopes allow a greater horizontal level displacement, consequently leading to more extensive flooding. The opposite occurs on beaches with steeper slopes.

We have monitored the events relating to meteorological tides on Cassino Beach, along with the formation, the trajectory, and the dissipation of cyclones, in the quest for a better understanding of the interaction between the ocean and the atmosphere in the southwest of the Atlantic Ocean and their influence on the high sea level rise on the coast of Rio Grande do Sul state. We sought, therefore, the atmospheric patterns responsible for the most extensive flooding and the erosion associated with it, through a qualitative and quantitative analysis of the morphological changes that take place on Cassino Beach.

\section{Methodology}

\section{Meteorological Data}

The atmospheric conditions prevailing during the formation, propagation, and dissipation of extratropical cyclones over the southwestern Atlantic Ocean were reconstituted with the aid of the database of the Reanalysis Project R-1 from National Center for Environmental Prediction (NCEP/NCAR) (KALNAY et al., 1996). The meteorological variables used were the zonal and meridional 10-meter wind component, and the sea level atmospheric pressure, both with a $2.5^{\circ} \times 2.5^{\circ}$ spatial resolution, and a 6-hour temporal resolution $(0000,0600,1200,1800$ UTC), limited to latitudes $60^{\circ} \mathrm{S}$ to $25^{\circ} \mathrm{S}$ and longitudes $80^{\circ} \mathrm{W}$ to $25^{\circ} \mathrm{W}$ (KALNAY, op. cit.).

The atmospheric situation on the day when the sea level reached its maximum height was reconstituted, together with those prevailing for the 2day period immediately before the event. The maximum was determined by using a videomonitoring system installed on Cassino Beach. We have adopted this methodology because the oceanic changes take place slightly more slowly than those that occur in the atmosphere; there is thus a time lag between the action of the wind and the meteorological tide's response (XAVIER; SARAIVA, 2000).

The direction, intensity, formation and duration of the wind fetch, the atmospheric pressure gradients and the trajectories of the cyclones were analyzed. The time interval considered was the total lifetime of the cyclone. The cyclone trajectories were calculated from the sequence of the relative vertical vorticity $\left(\zeta_{10}\right)$ in the center of the cyclone (ROCHA et al., 2003), by using the maximum negative vorticity of the geostrophic wind on the fields of the zonal $\left(\mathrm{u}_{10}\right)$ and the meridional $\left(\mathrm{v}_{10}\right)$ wind component at 10 -meter height, in the equation:

$$
\zeta_{10}=\frac{\partial v_{10}}{\partial x}-\frac{\partial u_{10}}{\partial y}
$$

where $u_{10}$ and $v_{10}$ are, respectively, the zonal and the meridional wind component measured at 10 -meter height, $x$ representing the east-west direction, and $y$ the north-south.

The threshold $\zeta_{10}=-1.5 \times 10^{-5} \mathrm{~s}^{-1}$ proposed by Reboita et al. (2005), which permits the detection of systems of lower intensity, has been adopted where values below this threshold were considered cyclones. After collecting the events with similar atmospheric patterns, we classified them according to the magnitude of the rise in sea level during the meteorological tide.

\section{Morphodynamic data}

Topographic profiles were carried out transversally to the coast before and after the extreme events of the high sea level rises. The measurements were made with the help of a station Nikon DTM-330 and an optical prism whose datum was a concrete bar installed on the foredunes of Querência Beach, $3 \mathrm{~km}$ south of the center of Cassino. 
The following morphometrical parameters, developed by Short and Hesp (1982), were determined for the purpose of determining the susceptibility to erosion associated with the events based on the topographical profiles: 1) the quantitative variation of the sediment volume on the beach subaerial region defined by an integral function; 2) the mean width of the beach $(\gamma b)$ defined by the distances between the limit of the dunes and the backshore and the position where the pre-event profile intercepted the datum; 3) the variation of the mean width of the beach $(\sigma \gamma b)$ calculated by the standard deviation of these widths; 4 ) the variation coefficient of this width $(C v)$ which defines the ratio (\%) $\sigma \gamma b: \gamma b$; and 5 ) the steepness of the beach $(\beta)$ in degrees.

A fixed spot at the end of the foredunes, $70 \mathrm{~m}$ from the Referential Level (RL) was adopted as the beginning of the backshore, and the distance from this spot to the spot where the profiles reached zero elevation was considered the beach width.

The pre-storm and the post-storm profiles were compared qualitatively in order to evaluate the morphological changes, the migration of berm and sand bars, the erosion/accretion of embryonic foredunes and the variations on the backshore. The intensity of the events was also classified according to the respective erosive impacts on the beach, regarding the sand volume $\left(\mathrm{m}^{3} \cdot \mathrm{m}^{-1}\right)$, in accordance with Tozzi and Calliari (1999).

\section{Hydrodynamic Data}

The values of the meteorological tide were estimated taking into account the overpositioning of the maximum displacement of the water line on the topographic profile before the event; this methodology was applicable because the coordinate system of the profiles coincides with the horizontal axis (x) of the images. The position of the beach line at the time of the maximum range of the sea level was superimposed on the profile preceding the event in order to ascertain the elevation $(\mathrm{z})$ in relation to the datum.

The beach line was considered to be the zone immediately in contact with the sea water, i. e., the limit between the land and the sea; it changes constantly according to the variations of the sea level. The beach line was determined by the Argus Images which were obtained through a video-monitoring system installed on Cassino Beach (Calliari et al., 2005). The method used to determine the beach line has been detailed in Guedes et al. (2007) and Parise et al. (2008).

The forecast value of the astronomical tide supplied by the Diretoria de Hidrografia e Navegação da Marinha do Brasil (www.mar.mil.br/dhn/chm/tabuas) was subtracted from the maximum elevation during each event.
Consequently, the high sea level rises were obtained for each event.

\section{RESUlts AND Discussion}

Twenty-three events of intense meteorological tides were monitored between June 2006 and July 2007. They were more frequent in autumn and winter, with $35 \%$ predominance in each season, followed by spring (17\%) and summer (13\%). The monitoring carried out by Saraiva et al. (2003) from April 1997 to July 1999 on Cassino Beach indicated the highest frequency of the phenomenon in autumn $(65 \%)$, followed by similar values in summer and spring $(15 \%)$ and lower values in winter $(5 \%)$. This frequency of the events in autumn and winter is associated with the more intense winds from the south of Brazil.

The estimated values for the meteorological tide attained, on average, $1 \mathrm{~m}$ elevation; the maximum recorded was $1.9 \mathrm{~m}$ in June 2007 during the $22^{\text {nd }}$ event (Fig. 1). Nevertheless, the astronomical tide together with the meteorological tide during the 6th event caused the biggest rise in sea level in the period monitored and occurred in spring under Syzygy tide conditions (Fig. 9).

Winds from the southwest occurred in $70 \%$ of the cases and were fundamental to the occurrence of the sea level elevations, since their association with the general northeast-southwest orientation of the coast line and the Coriolis effect favors the rise in the water level on the coast in Rio Grande do Sul state. In this research project, $39 \%$ of events showed that at least 24-hour period of wind action is necessary for the meteorological tide to attain its maximum amplitude. Xavier (2003) concluded that the events that occur in the region under study attain their maximum rises in level within a period of from 12 to 24 hours of wind action. Further, the major events studied by Saraiva et al. (2003) also needed the same time to reach their maximum amplitudes (Table 2). This can be explained as the time necessary for the transfer of momentum from the atmosphere to the ocean to occur.

The values of the sea level rises show that they are better correlated with the meridional component of the wind $(r=0.66)$ than with the zonal component, a fact that brings out the importance of the winds in the south quadrant. Xavier (2003) discusses the fact that the zonal component of the wind does not correlate well with the variation in level and attributed this to the meridional component of the wind (northsouth) due to the extensive wind fetch generated by the passage of cyclones in the southwestern Atlantic Ocean. 
Table 1. Atmospheric and oceanic data during the events. LP: the lower pressure in the cyclone during the period of observation; Wave height: from Wave Watch model in depth of 20m. Time: time interval between the cyclone formation and the maximum elevation of the meteorological tide.

\begin{tabular}{|c|c|c|c|c|c|c|c|c|}
\hline Year & Month & $\begin{array}{c}\text { Period of } \\
\text { observation }\end{array}$ & $\underset{\text { (mbar) }}{\mathbf{L P}}$ & $\begin{array}{c}\text { Maximum } \\
\text { wind intensity } \\
(\mathrm{m} / \mathrm{s})\end{array}$ & $\begin{array}{c}\text { Maximum } \\
\text { wind direction }\end{array}$ & $\begin{array}{c}\text { Wave height } \\
\text { (m) }\end{array}$ & $\underset{\text { (h) }}{\text { Time }}$ & $\begin{array}{c}\text { Meteorological } \\
\text { tide } \\
(\mathbf{m})\end{array}$ \\
\hline \multirow{10}{*}{2006} & June & 17 to 21 & 963,3 & 12,8 & SW & 2,28 & 6 & 0,485 \\
\hline & June & 21 to 29 & 992,6 & 23,2 & $\mathrm{~S}$ & 3,84 & 18 & 1,266 \\
\hline & Jul & 7 to 11 & 986,3 & 13,5 & SW & 1,75 & 36 & 0,817 \\
\hline & Jul/Aug & 25 to 3 & 979,9 & 23,4 & SW & 2,67 & 30 & 1,817 \\
\hline & Aug & 19 to 25 & 982,5 & 21,6 & SW & 3,24 & 24 & 1,847 \\
\hline & Sept & 01 to 08 & 970,7 & 26,6 & SW & 3,24 & 42 & 1,827 \\
\hline & Sept & 22 to 26 & 977,7 & 22,1 & SW & 2,29 & 30 & 0,927 \\
\hline & Sept & 26 to 29 & 979,6 & 12,9 & $\mathrm{~S}$ & 3,84 & 48 & 0,487 \\
\hline & Oct & 4 to 13 & 987,3 & 12,7 & $\mathrm{~S}$ & 2,44 & 24 & 0,127 \\
\hline & Nov & 2 to 13 & 974,9 & 24,2 & SW & 2,94 & 36 & 0,737 \\
\hline \multirow{13}{*}{2007} & Nov/Dec & 24 to 16 & 965,4 & 12,1 & SW & 1,93 & 30 & 0,447 \\
\hline & Feb & 4 to 9 & 969,7 & 13,7 & SW & 1,82 & 24 & 0,937 \\
\hline & Feb & 14 to 24 & 983,3 & 11,1 & SW & 2,02 & 6 & 0,897 \\
\hline & Mar/Apr & 31 to 14 & 978,8 & 15,2 & $\mathrm{~S}$ & 2,62 & 18 & 0,922 \\
\hline & Apr & 25 to 29 & 964,7 & 17,3 & SW & 2,56 & 48 & 1,452 \\
\hline & May & 6 to 11 & 989,7 & 15,5 & SW & 3,28 & 48 & 0,622 \\
\hline & May & 22 to 27 & 970,9 & 18,3 & $\mathrm{~S}$ & 3,2 & 24 & 1,077 \\
\hline & May & 27 to 31 & 990,5 & 18 & $\mathrm{~S}$ & 3,11 & 48 & 1,067 \\
\hline & May/June & 31 to 7 & 965,5 & 14,4 & SW & 2,87 & 36 & 1,147 \\
\hline & June & 7 to 20 & 979,8 & 11,9 & $\mathrm{~S}$ & 2,72 & 24 & 0,747 \\
\hline & June & 20 to 28 & 965,4 & 18,8 & SW & 2,41 & 24 & 0,897 \\
\hline & June/Jul & 28 to 5 & 974,5 & 18,8 & SW & 2,12 & 48 & 1,947 \\
\hline & Jul & 2 to 17 & 973 & 16,8 & SW & 2,67 & 18 & 1,027 \\
\hline
\end{tabular}

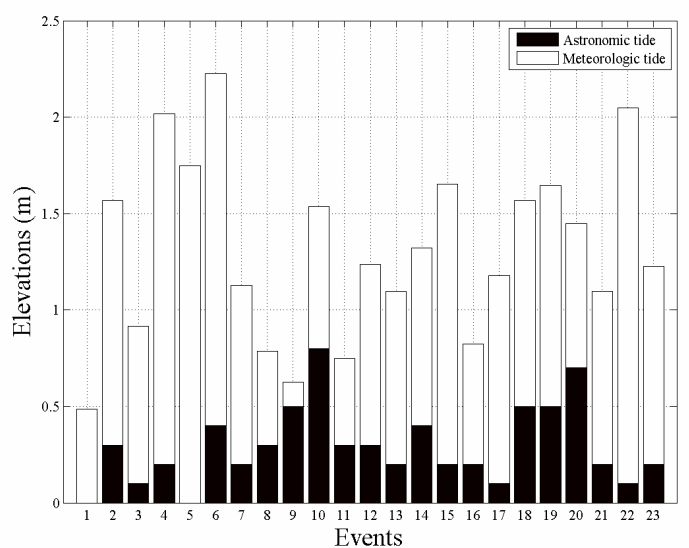

Fig. 1: The maximum sea level elevations due to astronomic and meteorological tide during each event. 
Table 2: Time interval between the formation of the cyclone and the maximum elevation of the meteorological tide.

\begin{tabular}{ccccc}
\hline \hline MONITORING & 6h & $\mathbf{2 4 h}$ & $\mathbf{3 6 h}$ & $\mathbf{4 8 h}$ \\
\hline $\begin{array}{c}\text { 1997 to } 1999 \\
\text { (Saraiva } \text { et al., 2003) }\end{array}$ & $10 \%$ & $45 \%$ & $10 \%$ & $30 \%$ \\
$\begin{array}{c}\text { 2006 to } 2007 \\
\text { (this research) }\end{array}$ & $9 \%$ & $39 \%$ & $26 \%$ & $26 \%$ \\
\hline
\end{tabular}

We have observed that the maximum values of the erosion were associated with the events of longer duration, rather than with the maximum rise in level. Experiments carried out in a wave tank, for the purpose of analyzing the erosive processes due to the action of storm waves and the later recovery of the beach morphology, have led to the conclusion that changes in beach morphology are more sensitive to the duration of the meteorological tide than to its elevation (SON; NODA, 1999).

\section{Analysis of the Cyclone Trajectories}

Reboita et al. (2005) compared two methods of detecting cyclones and their trajectories objectively, in order to ascertain the best method to evaluate cyclones in the southwestern Atlantic Ocean. These methods are based on vorticity and on surface pressure, and described in Rocha et al. (2003). They discovered that the first method is more efficient because a higher number of occurrences of cyclones were detected.

This study used the methodology of cyclone detection by means of maximum relative vorticity and found three trajectory patterns for cyclones associated with 23 meteorological tide events:

- PATTERN I: Cyclogenesis to the south of the Argentinian coast, with a displacement to the east and a trajectory between $47.5^{\circ} \mathrm{S}$ and $57.5^{\circ} \mathrm{S}$ (Fig. 2);

- PATTERN II: Cyclogenesis to the south of the Uruguayan coast with a displacement to the east and a trajectory between $35^{\circ} \mathrm{S}$ and $42.5^{\circ} \mathrm{S}$ (Fig. 3); and

- PATTERN III: Cyclogenesis to the south of the Uruguayan coast with a displacement to the southeast and a trajectory between $35^{\circ} \mathrm{S}$ and $57.5^{\circ} \mathrm{S}$ (Fig. 4).

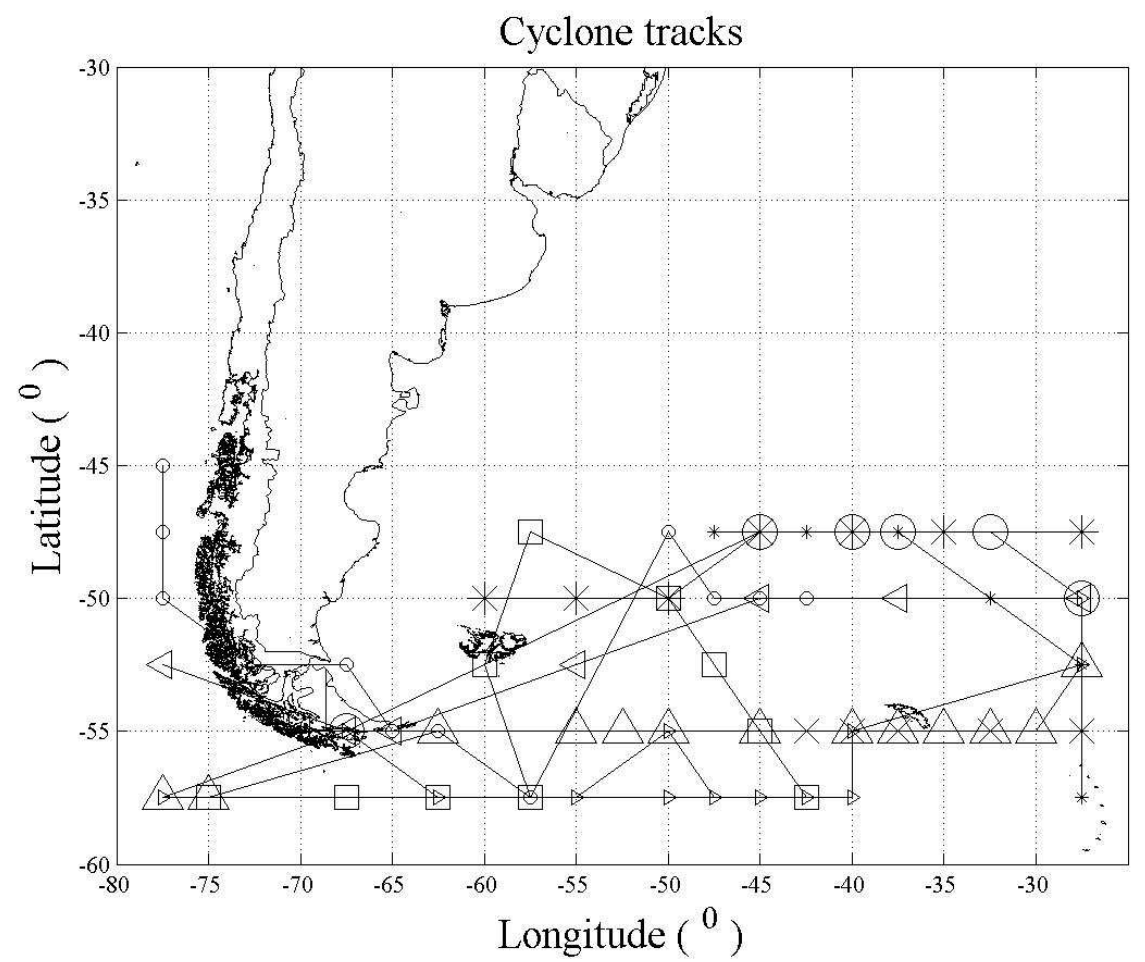

Fig. 2. Cyclone tracks between $47.5^{\circ} \mathrm{S}$ and $57.5^{\circ} \mathrm{S}$, from the time of detection to their dissipation over the ocean. Each trajectory is plotted with the same symbols, that is, each symbol represents a different trajectory. 


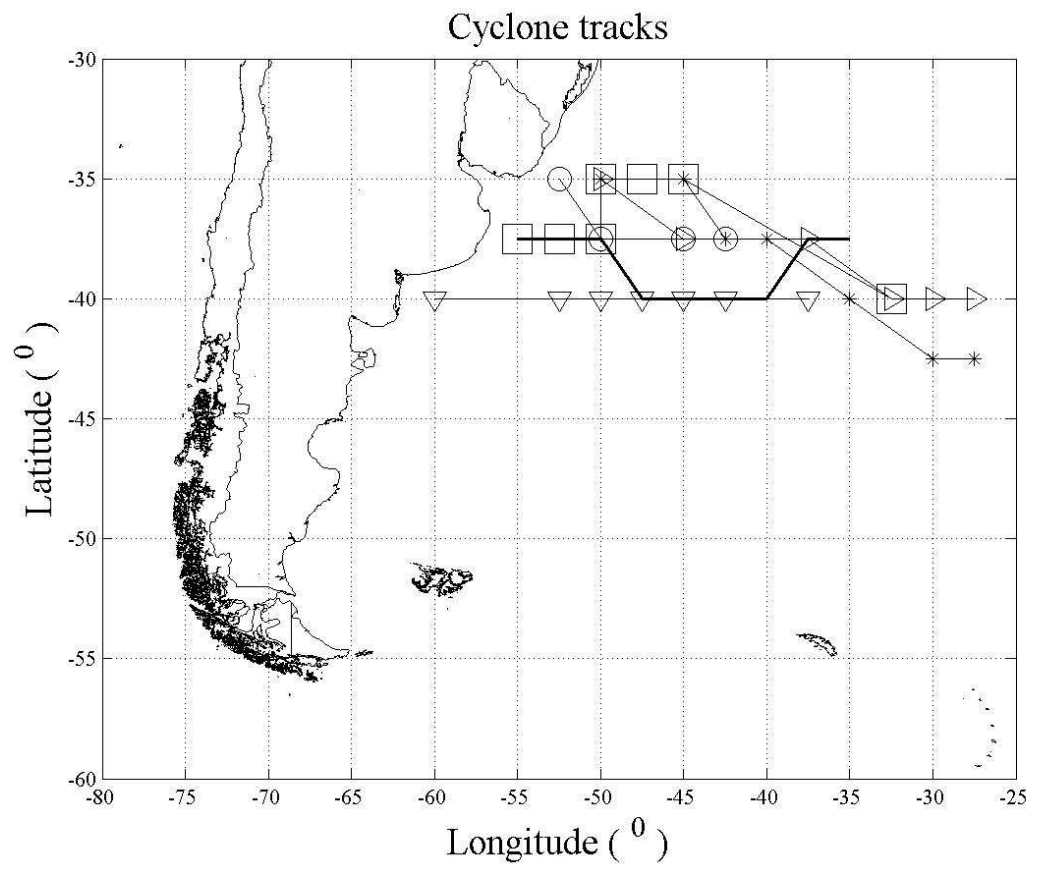

Fig. 3. Cyclone tracks between $35^{\circ} \mathrm{S}$ and $42.5^{\circ} \mathrm{S}$, from the time of detection to their dissipation towards the ocean. Each trajectory is plotted with the same symbols, that is, each symbol represents a different trajectory, including the bold line.

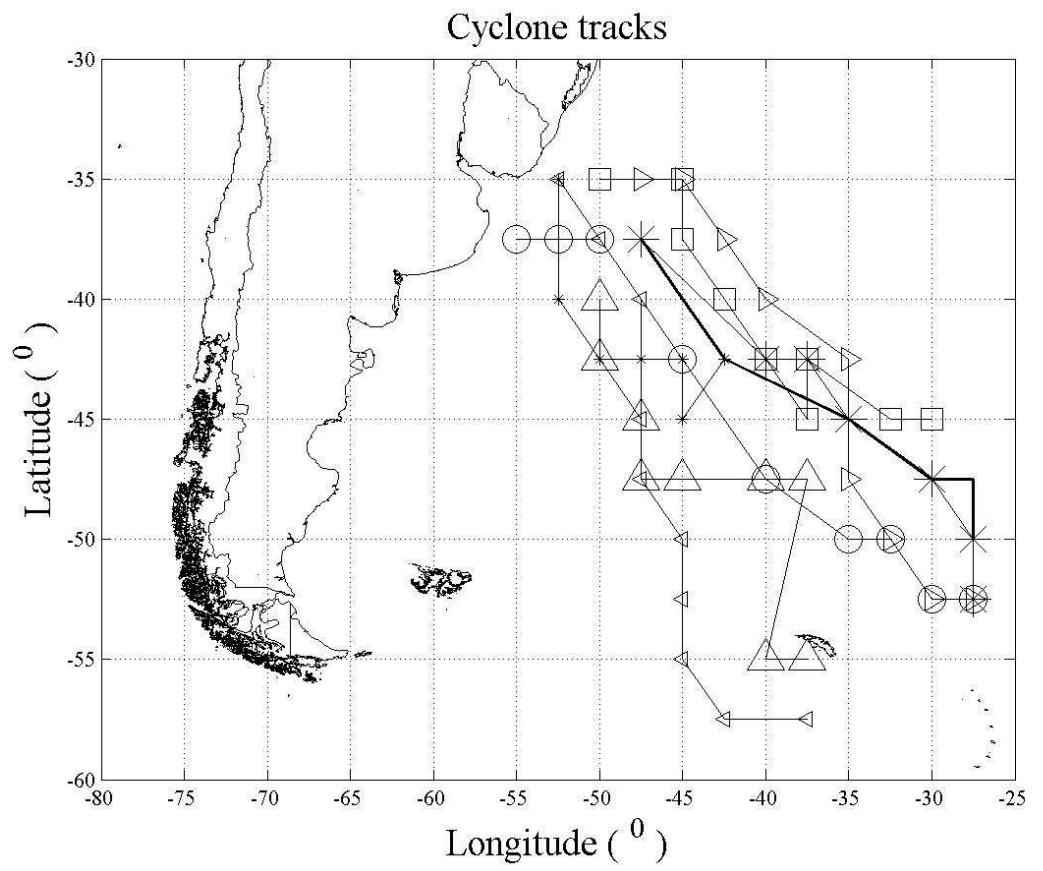

Fig. 4. Cyclone tracks between $35^{\circ} \mathrm{S}$ and $57.5^{\circ} \mathrm{S}$, from the time of detection to their dissipation towards the ocean. Each trajectory is plotted with the same symbols, that is, each symbol represents a different trajectory, including the bold line. 
Classification of the Intensity of the Events

After grouping the events in distinct cyclone trajectory patterns in the southwestern Atlantic Ocean, we attempted to relate them to different coastal impacts. To accomplish this, we used the methodology proposed by Tozzi and Calliari (1999). They utilized a classification for the intensity of storms based on the variation of the sedimentary volume on the subaerial part of the beach, i. e., between the water line and the dunes. According to these authors, values below 10 $\mathrm{m}^{3} \cdot \mathrm{m}^{-1}$, and others ranging between 10 and $20 \mathrm{~m}^{3} \cdot \mathrm{m}^{-1}$, 20 and $50 \mathrm{~m}^{3} \cdot \mathrm{m}^{-1}$, and 50 and $80 \mathrm{~m}^{3} \cdot \mathrm{m}^{-1}$ are classified as low, moderate, significant, and severe impact, respectively (Table 3).

Calliari et al. (1998) monitored the erosion between Rio Grande and the Chuí during storms and found maximum variations in the subaerial volume of the order of $60 \mathrm{~m}^{3} \cdot \mathrm{m}^{-1}$ and $10 \mathrm{~m}^{3} \cdot \mathrm{m}^{-1}$ for the beaches south and north of the Albardão Lighthouse, respectively.

According to Tozzi and Calliari (1999), the cycle of severe storms on the coast of Rio Grande do Sul state starts in April and acts during autumn and winter, due to significant changes in the trajectories and the distribution of extratropical storms in the southwestern Atlantic Ocean. These authors believe that cyclones very close to the beach result in a severe localized impact, whereas the storms further out over the ocean generate comparatively lower impacts more widely distributed along the coast (Table 3). The classification proposed by these authors fits the trajectories of the events investigated in this study.

The events of significant impact and trajectory near the coast, according to the classification previously mentioned, follow trajectory pattern II proposed in this study. Since in this pattern the cyclone stays near the coast for longer, the impact is more localized, and represents the most harmful event in terms of coastal risks for Cassino Beach.

On the other hand, events with moderate impact and a trajectory over the ocean fit trajectory pattern I proposed in this study; their cyclogenesis occurs off the south of Argentina and their trajectory is limited to between $47.5^{\circ} \mathrm{S}$ and $57.5^{\circ} \mathrm{S}$.

Finally, the maximum values for meteorological tides occurred when the associated cyclones formed off Uruguay and dislocated southeastwards. This trajectory pattern III allowed the formation of stronger wind fetches', a fact that favored the transfer of momentum and, consequently, the occurrence of higher rises in sea level.

Significant impacts were caused by the 11th, 15th, and 16th events, which occurred in November/December, April and May, respectively. Moderate impacts were associated with the 4th, 8th, and 12th events, in July/August, September and February, respectively. The other events caused little impact. Respective values regarding erosion in the subaerial profile correspond to $45.6 \mathrm{~m} 3 . \mathrm{m}-1,32.8$ m3.m-1, 37.5 m3.m-1, 18.7 m3.m-1, 10.5 m3.m-1, and 18 m3.m-1 (Fig. 5).

Some cases stand out and deserve to be concisely presented in this study, because they come within the three trajectory patterns described above.

\section{Case Studies}

Among the extreme meteorological events which were responsible for causing sediment remobilization and the consequent erosion, some stand out and deserve to be concisely presented in this study.

Of the three events which had a significant impact on Cassino Beach, two followed trajectory pattern II, with the formation of the low pressure center in the potential area of cyclogenesis between $30^{\circ} \mathrm{S}$ and $40^{\circ} \mathrm{S}$, proposed by Gan and Rao (1991).

Table 3. Main characteristics' of extratropical storms in the southern Atlantic Ocean, defined by Tozzi (1999). Source: Adapted from Tozzi and Calliari (1999).

\begin{tabular}{|c|c|c|c|c|}
\hline \multirow{2}{*}{ CHARACTERISTICS } & \multicolumn{4}{|c|}{ STORMS } \\
\hline & $\mathrm{E} / \mathrm{SE}$ & S/SE & $\begin{array}{l}\text { MIDDLE OF THE } \\
\text { ATLANTIC OCEAN }\end{array}$ & $\begin{array}{l}\text { EXTRATROPICAL } \\
\text { CYCLONES }\end{array}$ \\
\hline Waves & 0.5 a $1 \mathrm{~m}$ & $1 \mathrm{a} 1.5 \mathrm{~m}$ & $>1.5 \mathrm{~m}$ & $>2 \mathrm{~m}$ \\
\hline High sea level elevation & $<0.5 \mathrm{~m}$ & $\sim 1 \mathrm{~m}$ & $>1 \mathrm{~m}$ & $>>1 \mathrm{~m}$ \\
\hline Location & far & near & along/far & near/along \\
\hline Subaerial volume & $<10 \mathrm{~m} 3 / \mathrm{m}$ & 10 to $20 \mathrm{~m} 3 / \mathrm{m}$ & 20 to $50 \mathrm{~m} 3 / \mathrm{m}$ & 50 to $80 \mathrm{~m} 3 / \mathrm{m}$ \\
\hline Impact & low & moderate & significant & Severe \\
\hline
\end{tabular}




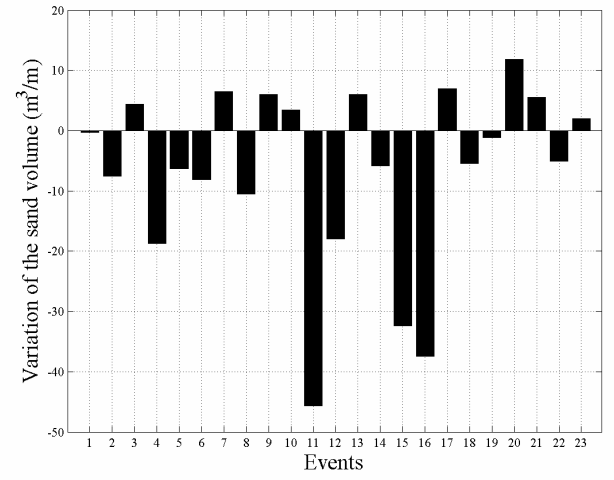

Fig. 5. Variation of the sand volume in $\mathrm{m}^{3} \cdot \mathrm{m}^{-1}$ during the events of meteorological tides.

The cyclone started its trajectory on the coast of Rio Grande do Sul state and moved to the east along the same latitude until it dissipated later over the ocean (Fig. 6). The events that had a significant impact, corresponding to the criteria proposed by Tozzi and Calliari (1999), were the 11th, 15th, and $16^{\text {th }}$, arose close to the coast and dislocated eastwards.
There were three meteorological tide events which caused moderate impact; they followed trajectory pattern I with the formation of the low pressure center in Argentina, moving away from the coast between $45^{\circ} \mathrm{S}$ and $50^{\circ} \mathrm{S}$ and then dissipating over the ocean. The 4th, 8th, and 12th events fit this classification since the cyclones did not go beyond $45^{\circ} \mathrm{S}$. The presence of an anticyclone was observed over the ocean, which may have blocked the passage of the cyclone to lower latitudes (Fig. 7).

Through the correlation of the synoptic events that presented maximum meteorological tide, we have found similar behavior patterns for the wind field and the atmospheric pressure at sea level. The cyclone which arose on the coast of Rio Grande do Sul state on September 2nd followed a southeasterly trajectory, reaching $45^{\circ} \mathrm{S}$, where it dissipated over the ocean within two days (Fig. 8).

This event, in spite of not having caused the most severe erosion, was responsible for the highest horizontal displacement of the sea level on Cassino Beach, with the invasion of the Beira Mar Avenue. It also prevented vehicles from driving on the beach (Fig. 9). Intense winds from the south quadrant formed a long SW wind fetch which lasted $48 \mathrm{~h}$ and was responsible for the rise of the water on the coast.
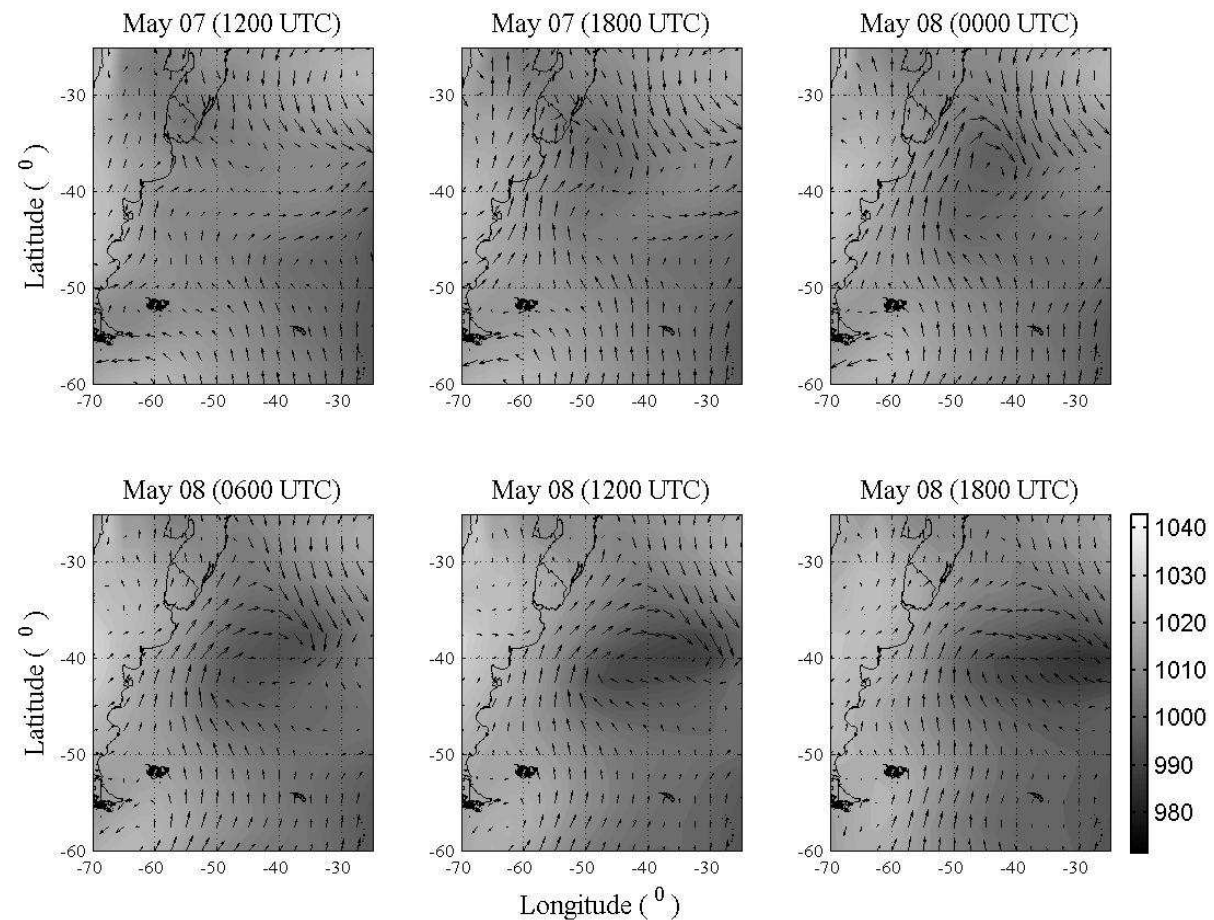

Fig. 6. Synoptic situation regarding the atmospheric pressure and the wind filed during the $16^{\text {th }}$ event. 

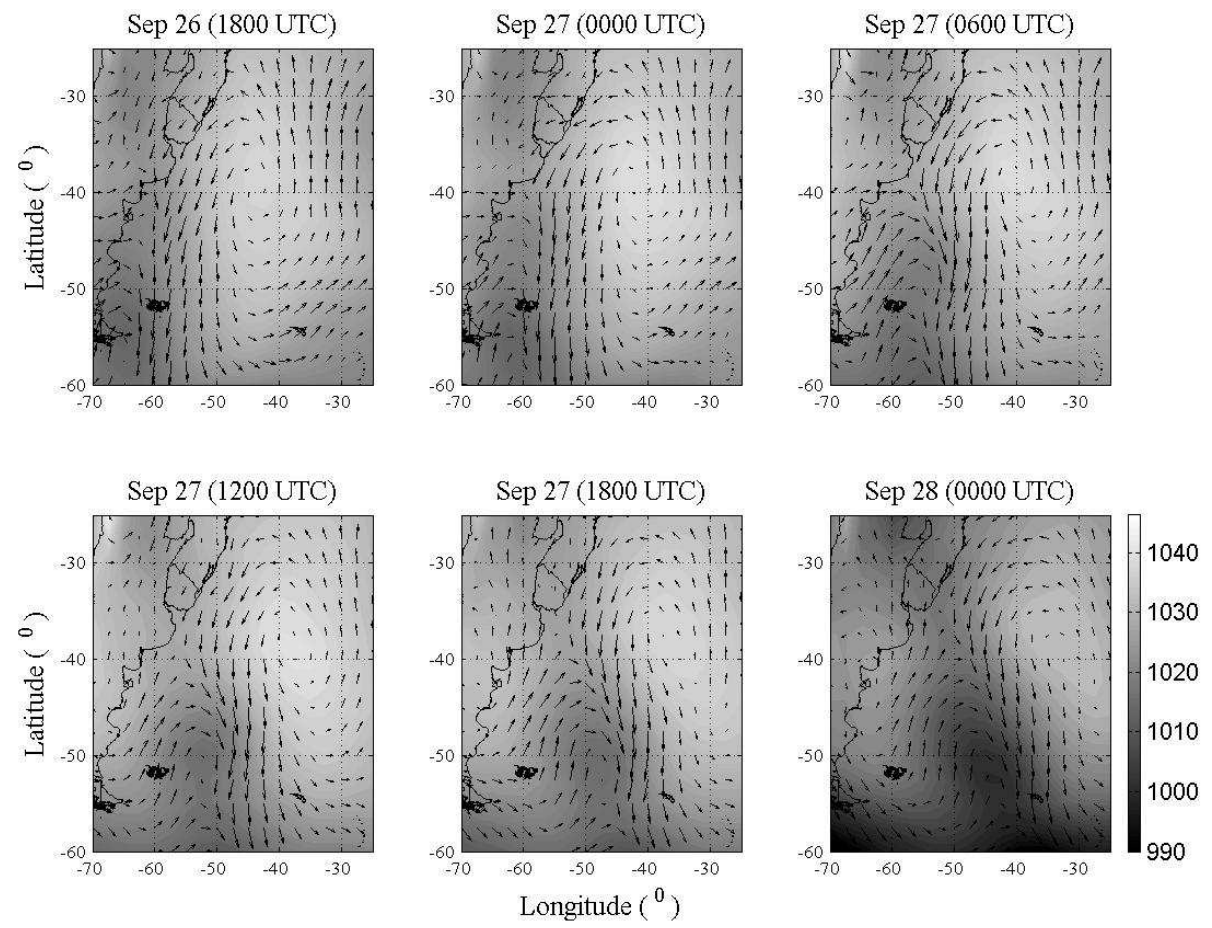

Fig. 7. Synoptic situation regarding the atmospheric pressure and the wind filed during the $8^{\text {th }}$ event.
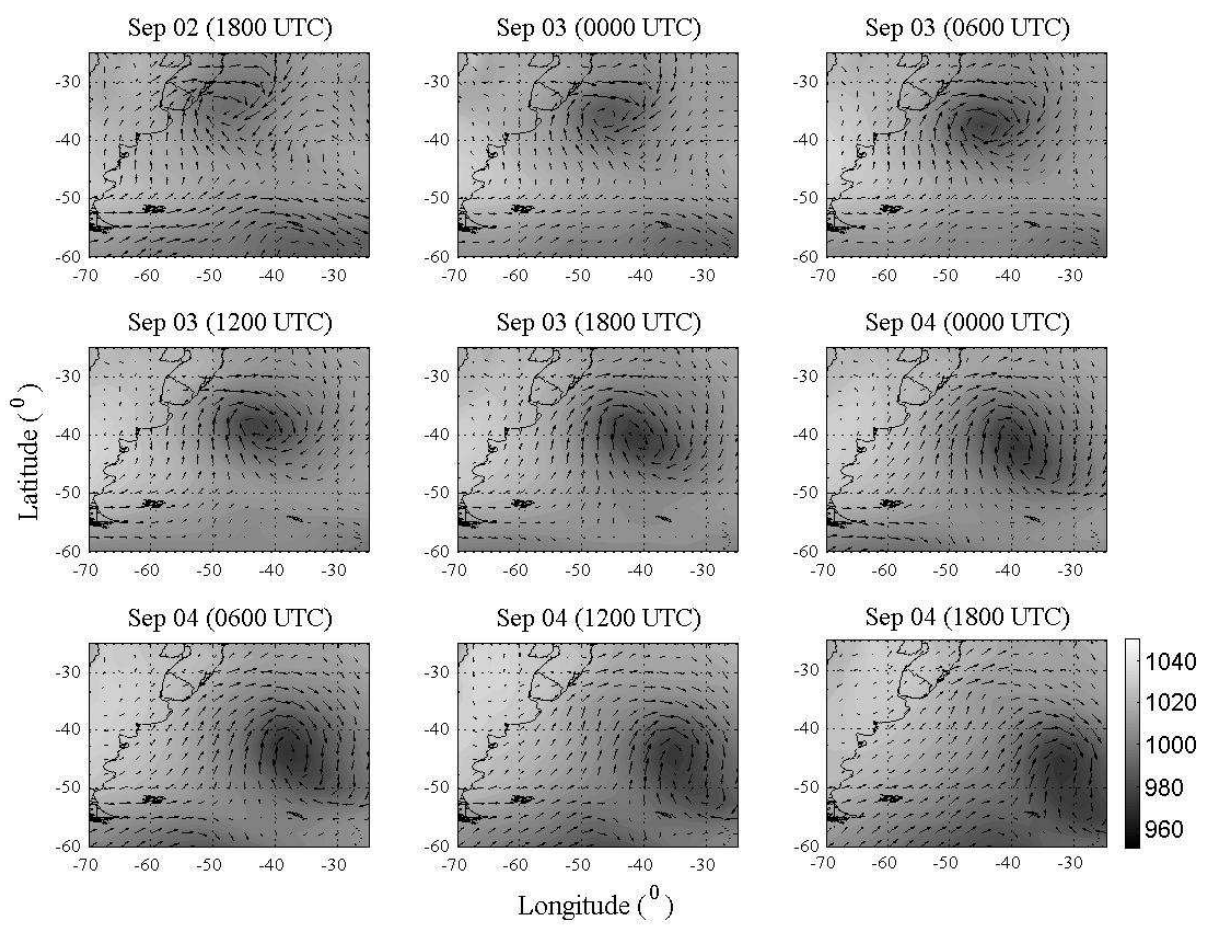

Fig. 8. Synoptic situation regarding the atmospheric pressure and the wind filed during the $6^{\text {th }}$ event. 


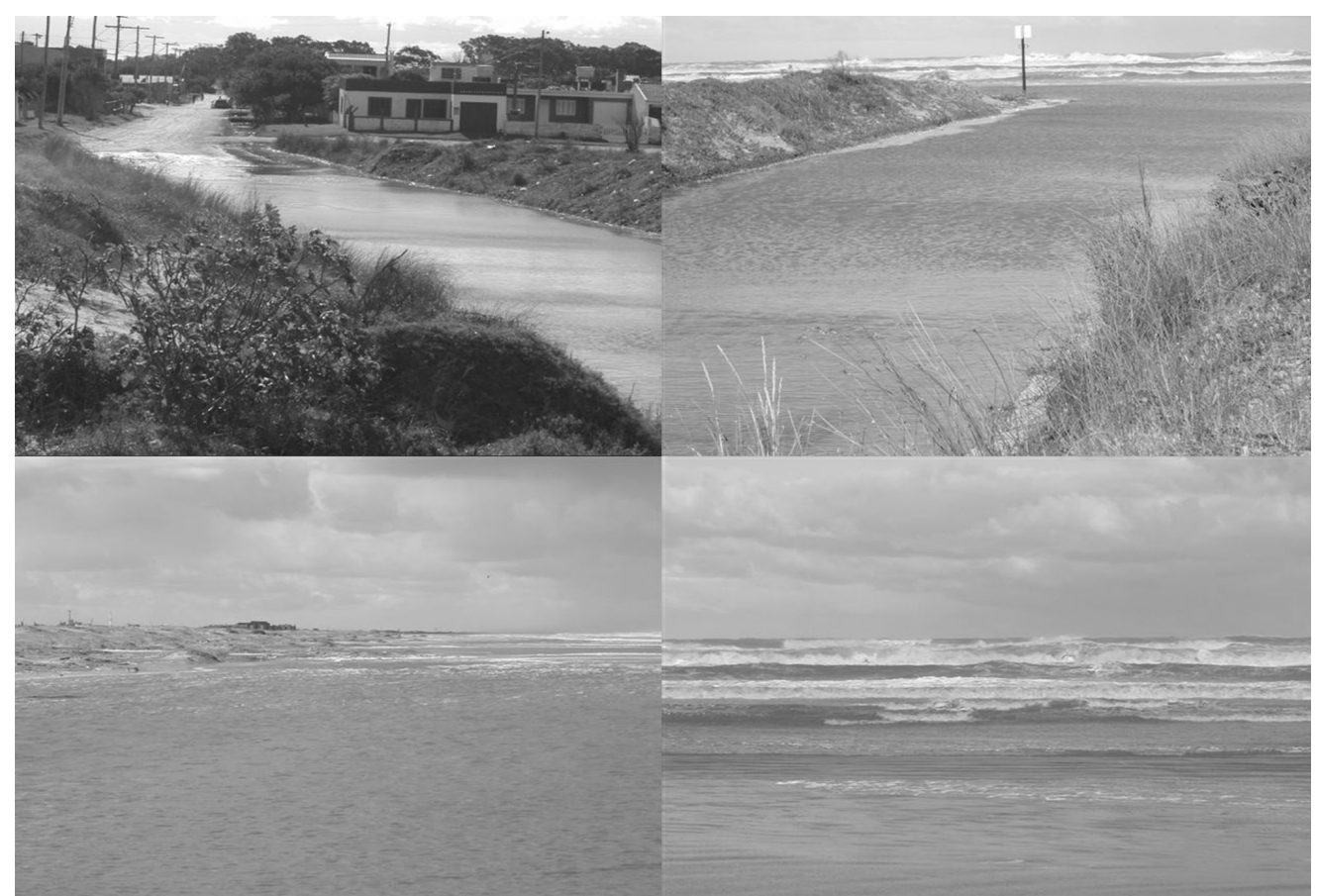

Fig. 9. An event of positive meteorological tide on Cassino Beach during the $6^{\text {th }}$ event $(9 / 4 / 2006)$.

\section{Behavior of Cassino Beach}

The topography of Cassino Beach presented the greatest variation in the subaqueous area, followed by the region of the embryonic dunes. Topographic profile data from autumn/winter 2005 and from summer 2006 for the same region were given to us by Guedes (2006) and Espírito Santo (2007), respectively, for comparison with the results of this paper. The present research showed high mobility as compared with that of the topography in the research carried out by Guedes (2006) and Espírito Santo (2007), who found high stability in this region (Fig. 10). This contrast may be explained by the reduced temporal scale used in both studies, since both include high frequency monitoring carried out in one single season. This present study, in turn, better reflects the seasonal variations that occur on the dunes, since it lasted one year and included all the seasons, including the spring, when NE winds are more frequent and transport more sand to the backshore region and the dunes.

We found a total variation of the subaerial sedimentary package of $145 \mathrm{~m}^{3} / \mathrm{m}$, indicating that Cassino Beach showed great topographic variability in the region between the foredunes and the beach line. This value does not include the variations that occurred in the subaqueous region, which permits us to affirm that the variation of the total sedimentary package is even higher, though the latest one showed the highest mobility. The highest topographic variation occurred in the subaqueous part, with a maximum value of $1.16 \mathrm{~m}$. It is explained by the constant variation and migration of the sand bars (Fig. 11). It indicates that a large part of the sediments removed from the beach face, where more severe erosion occurred specifically due to the action of the wind, contributed to the formation of the sand bars, since this region was very variable. On the dunes, three peaks of vertical variation of the package of the order of $1.36 \mathrm{~m}$ were observed. However, this change took place because of the wind power processes, rather than as a result of the meteorological tide, since the sea level did not reach this region in any of the events recorded.

Guedes (2006) recorded high migration rates from the second bar and attributed this movement to the variations in the height of the waves. This author also found that the migration of the bar towards the sea is associated with wave heights above $0.75 \mathrm{~m}$. The highest displacement of the bar towards the sea, recorded by the author, was of $8.7 \mathrm{~m} /$ day, due to the presence of a rip current. The bar crest was narrower and steeper in situations of coastward migration, and softer and more outspread when the migration was towards the sea. 
Topographic profile (from June of 2006 to July of 2007)

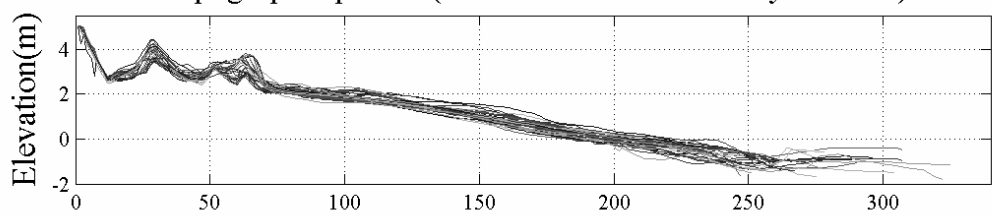

Topographic profile (from January and February of 2006)

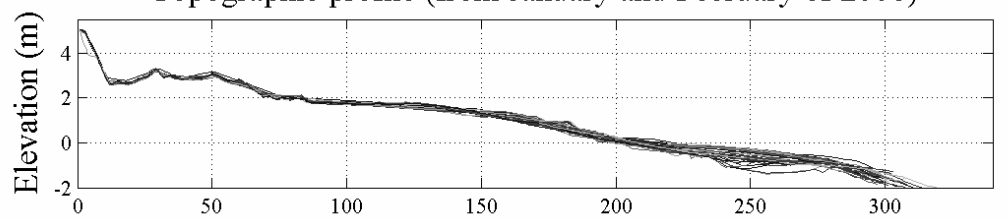

Topographic profile (from April and June of 2005)

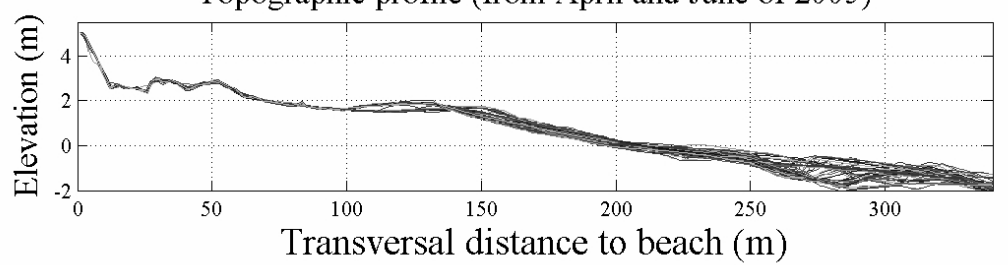

Fig. 10. Topographic variation on Cassino Beach: a) During this study; b) In summer 2006 monitorated by Espírito Santo (2007) and c) In autumn/winter 2005 monitorated by Guedes (2006).

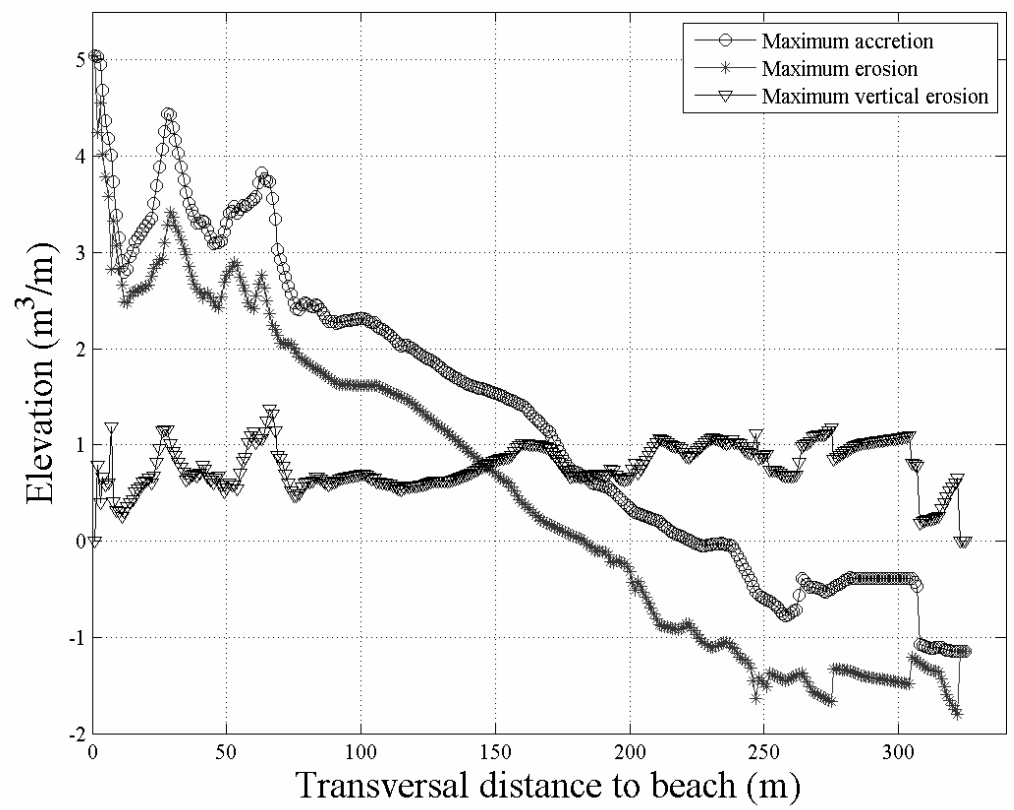

Fig. 11. Variation of the sedimentary package along the profile and vertically, based on the phase of maximum accretion and the maximum erosion on Cassino Beach. 
In spite of the width of the beach appearing to vary, we found that it decreased in winter and spring, from June to December 2006 (Fig. 12, profiles 1 to 19), started to increase at the beginning of summer attaining three maximum peaks (Fig. 12, profiles 21, 27 and 29) and began to decrease again in June 2008 (Fig. 12, profile 38). These characteristics show that, even though the morphodynamics of the beach are greatly influenced by cyclones that occur throughout the year, there is a seasonality profile defined by the frequency with which the cyclones occur in the region, more often in winter (narrower beach) and less frequently in summer (wider beach).
The morphometrical parameters proposed by Short and Hesp (1982) were calculated and have been summarized in Table 4.

Tozzi and Calliari (2000) found CV values equal to 3, 4, and 5 for three sectors on Cassino Beach from 1991 to 1996 , as well as mean volumes of the beach equal to 5,5 , and $4 \mathrm{~m}^{3} \cdot \mathrm{m}^{-1}$, respectively. Guedes (2006), in a study of high frequency on Cassino Beach in autumn and winter 2005, found the mean width of the beach to be $122 \mathrm{~m}$, its mobility index 5.2 $\mathrm{m}$, and the mobility index of the backshore $4.2 \mathrm{~m}$. Closely similar values were found by Espírito Santo (2007).

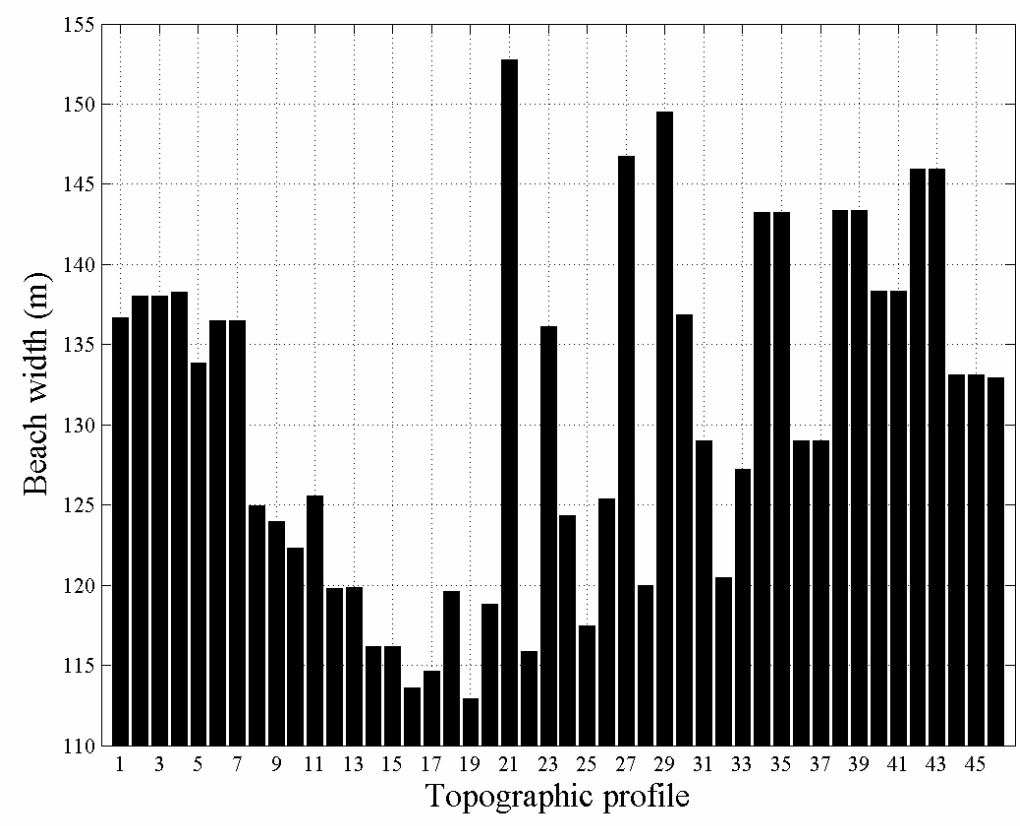

Fig. 12. Variation of the width on Cassino Beach during the events from June 2006 to July 2007, based on pre-event profiles (odd profiles) and post-event profiles (even profiles).

Table 4. Numbers of profiles (n); Mean width of the beach $(\gamma b)$; Mobility index of the beach ( $\sigma \gamma b)$; Mobility index of the backshore $(\mathrm{CV})$; Mean steepness of the beach face $(\beta)$; Mean volume of the beach $(\mathrm{Vv})$; Volume variation $(\sigma \mathrm{Vv})$.

\begin{tabular}{|c|c|c|c|c|c|c|}
\hline $\mathbf{N}$ & $\gamma \mathbf{b}(\mathbf{m})$ & $\sigma \gamma \mathbf{b}(\mathbf{m})$ & $\mathrm{CV}(\%)$ & $\beta\left({ }^{\circ}\right)$ & Vv $(\mathbf{m} 3 / \mathbf{m})$ & $\sigma \mathrm{Vv}(\mathrm{m} 3 / \mathrm{m})$ \\
\hline 46 & 130,6 & 10,89 & 8,4 & 1,19 & $-6,25$ & 14,75 \\
\hline
\end{tabular}


Of 23 events, $60 \%$ decreased the slope of the beach face, which presented a mean steepness of $1.19 \%$ and maximum variation of $1.92^{\circ}$ during a unique event. The high index of beach mobility (10.89 $\mathrm{m})$ and the increase in the backshore mobility index found in this study $(\mathrm{CV}=8.4)$ were due to the fact that it was mainly the effect of intense meteorological tides on the profile that was monitored, i. e., events of high hydrodynamic energy which are actually the ones that cause greater variations in the coastal profile. Even though a negative value was found $\left(-6.25 \mathrm{~m}^{3} \cdot \mathrm{m}^{-1}\right)$ for the mean volume of the beach (Table 4), it is too low to allow us to state that Cassino Beach showed a sedimentary deficit from June 2006 to July 2007, since the monitoring concerned aimed at quantifying only erosive events.

\section{Conclusions}

All the meteorological tide events monitored in this study were associated with extratropical cyclones occurring over the ocean. We found their three trajectory patterns over the southern Atlantic Ocean to be: 1) PATTERN I: Cyclogenesis in the south of Argentina with an eastward displacement and a trajectory between $47.5^{\circ} \mathrm{S}$ and $57.5^{\circ} \mathrm{S} ; 2$ ) PATTERN II: Cyclogenesis in the south of Uruguay with an eastward displacement and a trajectory between $35^{\circ} \mathrm{S}$ and $42.5^{\circ} \mathrm{S}$; and 3) PATTERN III: Cyclogenesis in the south of Uruguay with a southeasterly displacement and a trajectory between $35^{\circ} \mathrm{S}$ and $57.5^{\circ} \mathrm{S}$.

These results agree with the atmospheric patterns presented by previous studies (TOZZI; CALLIARI, 1999), but the method they used may contain errors, since the cyclone trajectories were determined on the basis of the visual analysis of the displacement of the center of low atmospheric pressure. However, the trajectory patterns found in this study were calculated by using the methodology proposed by Reboita et al. (2005), based on the maximum relative vorticity at the center of the cyclone.

The vorticity method is better able to detect cyclones in the southern Atlantic because it shows the favorite regions of the cyclogenesis more clearly. It may, therefore, be affirmed that the vorticity represents a more precise way to detect cyclone trajectories.

We may conclude that the synoptic atmospheric patterns that caused greater erosion on Cassino Beach occurred when the cyclones originated in the south of Uruguay with an eastward displacement and a trajectory between $35^{\circ} \mathrm{S}$ and $42.5^{\circ} \mathrm{S}$. This it is that the cyclone stays near the coast longer and, consequently, produces a more localized impact.
The maximum meteorological tide was estimated at $1.9 \mathrm{~m}$ (spring) and the synoptic situation which caused the highest elevations of the meteorological tide presented cyclogenesis in the south of Uruguay with an eastward displacement and trajectory between $35^{\circ} \mathrm{S}$ and $57.5^{\circ} \mathrm{S}$. This atmospheric pattern permitted the formation of a stronger wind fetch, the main factor leading to high sea level elevation.

We discovered that the erosive processes do not depend only on the intensity, trajectory, and magnitude of the events, but also on the characteristics of the profile prior to them, since the most erosive event occurred in summer.

The subaqueous region is where the highest variation of the topographic profile occurs in a short period of time, followed by the foredune region over a longer period of time.

The sedimentary rhythm on Cassino Beach shows destructive phases with successive high energy events, whereas longer periods of low hydrodynamics allow the re-composition of the morphology. The dissipative modal state oscillates, therefore, between intermediate and maximum secondary states according to the energetic regimen of the southern Atlantic Ocean.

\section{REFERENCES}

ALMEIDA, L. E. S. B.; ROSAURO, N. M. L.; TOLDO JR., E. E. Análise preliminar das marés na Barra do Rio Tramandaí, RS. In: SIMPÓSIO BRASILEIRO DE RECURSOS HÍDRICOS, 12., 1997, Vitória, E.S. Anais... Vitória, ES: ABRH, 1997, p 560-566.

BENAVENTE, J.; DEL RIO, L.; GRACIA, F. J.; MARTINEZ-DEL-POZO, J. A. Coastal flooding hazard related to storms and coastal evolution in Valdelagrana spit (Cadiz Bay Natural Park, SW Spain). Continent. Shelf Res., v. 26, p 1061-1076, 2006.

CALLIARI, L. J.; TOZZI, H. A. M. ; KLEIN, A. H. F. Beach morphology and coastline erosion associated with storm surge in Southern Brazil- Rio Grande to Chuí, RS. An. Acad. Bras. Ciênc., .v. 70, n. 2, 1998.

CALLIARI, L.J.; HOLAND, T.; DIAS M. S.; VINZON S.; THORTON E. B. E.; STANTON, T. P. Experimento Cassino 2005: uma síntese dos levantamentos efetuados na ante-praia e zona de arrebentação. In: CONGRESSO DA ASSOCIAÇÃO BRASILEIRA DE ESTUDOS DO QUATERNÁRIO, Vitória, ES, 2005. Anais ... Vitória, ES.: Associação Brasileira de Estudos do Quaternário (ABEQUA), 2005.

ESPÍRITO SANTO, R. M. 2007. Variabilidade morfodinâmica entre as regiões da Querência e do Navio Altair na Praia do Cassino, RS, 2007. Dissertação (Mestrado em Oceanografia Física, Química e Geológica). Departamento de Oceanografia Geológica, Fundação Universidade Federal de Rio Grande, RS, 2007. 
GAN, M. A.; RAO, B. V. Surface cyclogenesis over South America. Mon. Weath. Review, v. 119, p 293-302, 1991.

GUEDES, R. M. C. Morfodinâmica de alta freqüência de um sistema praial com bancos triplos durante o experimento cassino 2005. Trabalho de Graduação em Oceanologia. Laboratório de Oceanografia Geológica, Fundação Universidade Federal de Rio Grande, RS, 2006

GUEDES, R. M. C.; PEREIRA, P. S.; CALLIARI, L.J Determinação dos bancos arenosos e da linha de praia no Cassino, RS, através de perfis de praia e Imagens Argus. In: CONGRESSO LATINO-AMERICANO DE CIÊNCIAS DO MAR, 12., 2007, Florianópolis. Anais... Florianópolis: Assoc. Brasileira de Oceanografia, 2007.

KALNAY, E., KANAMITSU, M., KISTLER, R., COLLINS, W., DEAVEN, D., CANDIN, L., IREDELL, M., SAHA, S., WHITE, G., WOOLLEN, J., ZHU, Y., ROPELEWSKI, C., WANG, J., LEETMAA, A., REYNOLDS, ROY JENNE, R., JOSEPH, D. The NCEP/NCAR 40-year reanalysis project. Bull. Am. met. Soc., v. 77, p. 437-471, 1996.

MURTY, T. S. Storm surges-meteorological ocean tides Can. Bull. Fish. Aquat. Sci., v. 212, p 876-897, 1984.

PARISE, C. K.; GUEDES, R. M. C.; CALLIARI, L. J. 2008. Variação da linha de praia por marés meteorológicas utilizando um sistema de vídeo-imagem, Praia do Cassino, RS. In: CONGRESSO BRASILEIRO DE OCEANOGRAFIA, 3., 2008, Fortaleza, CE. Anais... Brasil: Assoc. Bras. Oceanografia, 2008.

PUGH, D. T. Tides, surges and mean sea level: A handbook for Engineers and Scientists. New York: John Wiley, 1987. p. 472.

REBOITA, M. S.; ROCHA, R. P.; AMBRIZZI, T. Climatologia de ciclones sobre o Atlântico Sul utilizando métodos objetivos na detecção destes sistemas. In: CONGRESSO ARGENTINO DE METEOROLOGIA., 9., 2005, Buenos Aires. Anais... Buenos Aires: CONGREMET, 2005.

ROCHA, R. P.; SUGAHARA, S.; DA SILVEIRA, R. B. Sea Waves Generated by extratropical cyclones in the South Atlantic Ocean: Hindcast and validation against Altimeter Data. Weather Forecasting, v. 19, n. 2, p 398-410, 2003.
SARAIVA, J. M. B.; BEDRAN, C.; CARNEIRO, C. 2003. Monitoring of storm surges on Cassino Beach. J. coast. Res., v. 35, Special Issue, p 323-331, 2003.

SHORT, A. D.; HESP, L. 1982. Wave, beach and dune interactions in Southeastern Austrália. Mar. Geol., v. 48, p 259-284., 1982.

SON, C. B.; NODA, H. Cross-shore beach profile response to storm surge. In: INTERNATIONAL SIMPOSIUM ON COASTING ENGINEERING AND SCIENCE OF COASTAL SEDIMENTS PROCESSES, Haupage, New York, 1999. Proceedings ..., 1999, p. 354-366.

TOZZI, H.A.M.; CALLIARI, L. J. Trajetórias e distribuição das tempestades extratropicais e o impacto na costa do Rio Grande do Sul. In: CONGRESSO LATINOAMERICANO DE CIÊNCIAS DO MAR 7.,1999, Porto Seguro. Anais... Porto Seguro, BA: 1999.

TOZZI, H. A. M.; CALLIARI, L. J. Morfodinâmica da Praia do Cassino, RS. Pesq. Geociênc., v. 27, n. 1, p 29-42, 2000.

XAVIER, A. L. M.; SARAIVA, J. M. B. Variações do nível do mar na costa em Rio Grande de 1977 a 1978. In: JORNADAS NACIONALES DE CIÊNCIAS DEL MAR, 4., 2000, Puerto Madrin-Chubut, AR. Anais... Puerto Madryn, AR, 2000.

XAVIER, A. L. M. Influência do padrão atmosférico nas marés meteorológicas na Praia do Cassino, Rio Grande, RS. Trabalho de graduação em Oceanologia. Laboratório de Oceanografia Geológica, Fundação Universidade Federal de Rio Grande, RS, 2003.

(Manuscript received 04 November 2008; revised 27 February 2009; accepted 24 April 2009) 